\title{
EQUIVALENT STABILIZING FORCE OF THE SIMPLY SUPPORTED ROOF GIRDERS INCLUDING THE LONGITUDINAL VARIABILITY OF THE COMPRESSION FORCE ACTING IN THE RESTRAINED CHORD
}

\author{
Antoni BIEGUS ${ }^{1}$, Dariusz CZEPIŻAK ${ }^{1}$ \\ Wroclaw University of Science and Technology, Wrocław, Poland
}

\begin{abstract}
In the calculation model of the equivalent stabilizing force $q_{d}$ for bracing system consistent with EN 1993-1-1 it has been conservatively assumed that the member to be restrained is uniformly compressed within its length by an axial force. This assumption is incorrect owing to the actual distribution of the axial force which is non-uniform in the shape of parabola. Thus a different imperfection force is generated in comparison with this given in EN 1993-1-1. In the paper the equivalent stabilizing force $q_{d}$ of simply supported roof girders has been analyzed. The formulas for an equivalent stabilizing forces of restrained roof girders with parabolic variability of axial force, have been proposed. Obtained results have been discussed and illustrated with examples.
\end{abstract}

Keywords: steel structures, lateral bracing system, equivalent stabilizing force, roof girder, member to be restrained, purlin,

\section{INTRODUCTION}

Accordingly with EN 1993-1-1 [4] the global analysis of the structure takes into account the geometrical imperfection like initial bow imperfection (Fig. 1b) of frame columns and restrained flanges of roof girders. For convenience, the effects of initial bow imperfections of the members to be restrained by a bracing system

\footnotetext{
${ }^{1}$ Corresponding author: Wroclaw University of Science and Technology, Faculty of Civil Engineering, Wybrzeże Wyspiańskiego 27, 50-370 Wrocław, Poland, tel. +48502578226, e-mail: antoni.biegus@pwr.edu.pl,dariusz.czepizak@pwr.edu.pl
} 
are replaced by the equivalent stabilizing imperfection force $q_{d 1}$ and reactions $R_{d 1}$ (Fig. 1d), that are determined from equations:

$$
\begin{gathered}
q_{d 1}=8 N_{E d} \frac{e_{0}}{L^{2}} \\
R_{d 1}=-4 N_{E d} \frac{e_{0}}{L}
\end{gathered}
$$

where: $N_{E d}$ - the axial force in a member, $e_{0}$ - the initial bow imperfection, $L$ - the span of restrained member.

a)

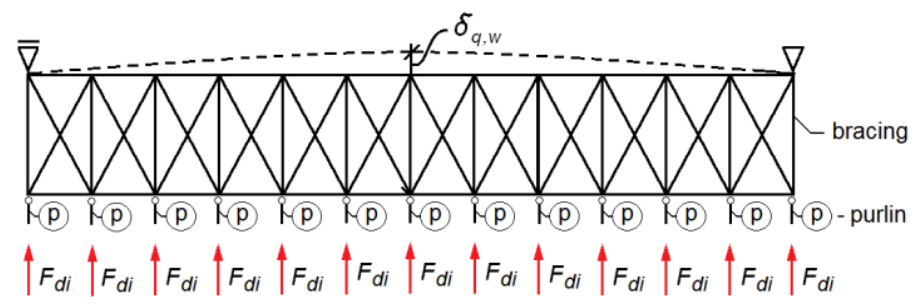

b)

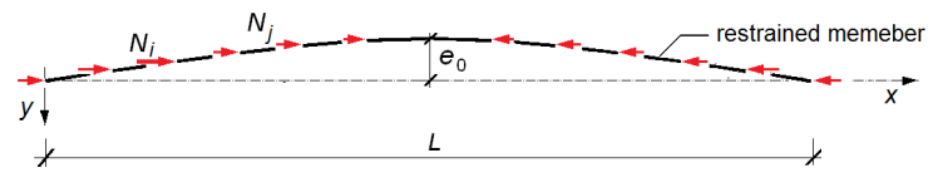

c)
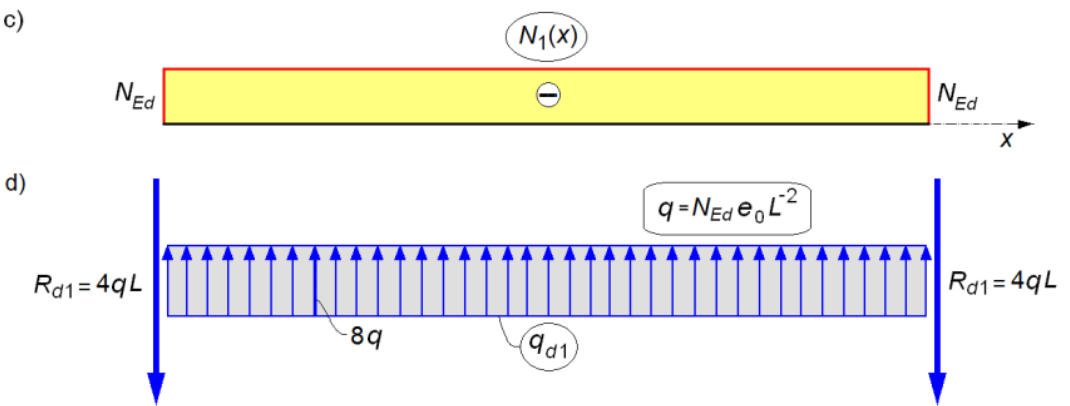

Fig. 1. Calculation model of bracing system according to EN 1993-1-1 [4]: a) scheme of a bracing system, b) scheme of a member to be restrained, c) distribution of $N_{1}(s)$ in the member, d) loadings $q_{d 1}$ from imperfections

The uniformly distributed imperfection force $q_{d 1}=$ const see (1) and reactions $R_{d 1}$ see (2) have been determined in situation where the axial compression force is $N_{1}(x)=$ const (Fig. 1c). This assumption is fulfilled by frame columns being under uniform compression. 
In the analysis of the bracing system (Fig. 1a) which provides the lateral stability of the compression flange of roof girders, the effect of imperfection in EN 19931-1 [4] is accounted for in the shape of their bow imperfection (Fig. 1 b):

$$
e_{0}=\frac{L}{500}
$$

In this model of calculation [3], [6], [7] the axial force is assumed to be uniform $N_{1}(\mathrm{x})=$ const (Fig. 1c) within the span $L$, and equal to the maximum force $N_{E d, \max }$ (1), (2) in the restrained member, which is conservative in case of the real nonuniform distribution of axial forces e.g., (Fig. 1c).

The total equivalent force $q_{d 1, m}$ from $m$ members to be restrained, transmitted to the lateral bracing (including its deformations) EN 1993-1-1 [4] is determined from expression:

$$
q_{d 1, m}=8 \frac{e+\delta_{q 1, w}}{L^{2}} \sum_{i=1}^{m} N_{E d, i}
$$

where: $N_{E d, i}$ - the maximum compressive force in the restrained member $i, \delta_{q 1, w}$ in-plane deflection of the lateral bracing system in the mid-span (Fig. 1a) caused by $q_{d 1}$ and all other external loads (e.g., wind load $w$ ) obtained from first order analysis (it may be assumed $\delta_{q 1, w}=0$ if second order analysis is used), $e$ - total imperfection of $m$ members to be restrained:

$$
e=\frac{L}{500} \sqrt{0.5\left(1+\frac{1}{m}\right)}
$$

For instance in single-span girders free supported at the ends (Fig. 2a, b), the compressive force has a quasi-parabolic distribution.

For this shape of distribution $(N(x) \neq c o n s t)$, the non-uniform arrangement of the equivalent stabilizing force within the length of restrained member is adequate $q_{d 2}(x) \neq$ const i.e., variable and with changeable signs. In [5], for an analysis of the non-linear distribution of forces, the equivalent stabilizing force $q_{d 2}(x)$ has been revealed in comparison with $q_{d 1}(x)=$ const, determined according to EN 1993-1-1 [4].

A refined, generalized models of calculation of equivalent stabilizing forces for restrained, simply supported roof girders have been proposed. In the analyses the parabolic distribution of the compressive forces acting in the restrained member $N(x) \neq$ const and its parabolic bow in the roof plane $e_{0}$ have been accounted. Obtained results have been discussed and illustrated with examples. 
a)

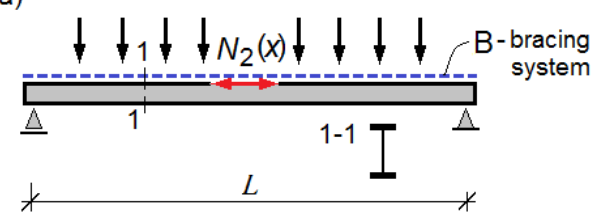

c)

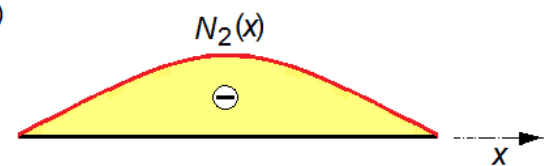

b)

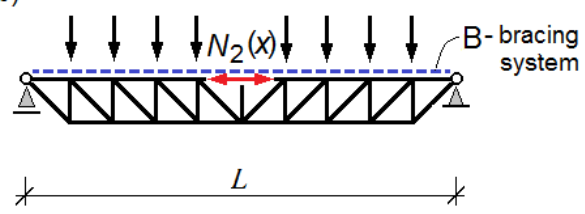

d)

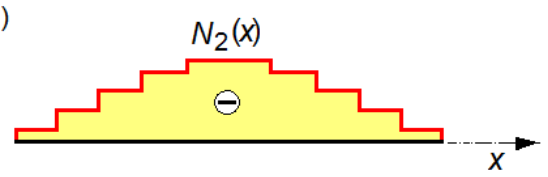

Fig. 2. Schemes of: a) simply supported plate girder, b) simply supported truss girder, c), d) distribution of the axial force in the restrained upper chord of the girders

\section{EQUIVALENT SABILIZING FORCE OF THE MEMBER IN COMPRESSION BY THE FORCE PARABOLICALLY VARYING WITHIN ITS LENGTH}

The equivalent stabilizing force of the single-span roof rafter that is free supported, symmetrically loaded, and laterally restrained in the roof plane (Fig. 2a, 3a) is considered. The distribution of compressive forces $N_{2}(x)$ within the length $x$ of its upper chord is quasi-parabolic (Fig. 2c, 3b). Variability of the longitudinal force throughout the length of the restrained member has been described by a parabolic function expressed in a parametric form:

$$
N_{2}(s)=4 N_{E d} s(1-s)
$$

where: $s=x / L$ - relative length of the restrained member in the range $\langle 0,1\rangle$.

In the analyzed calculation model the initial bow imperfection has been taken as second order parabola in the form:

$$
y(s)=4 e_{0} s(1-s)
$$

In [2] the general equations have been derived for both the equivalent imperfection force $q_{i}(\mathrm{~s})$ and reactions $R_{d i}$ of the restrained member that is subjected to the axial force varying within the member's length. In the case of symmetrical distribution of the force $N_{2}$ (s) in the restrained member (see Fig. 2c, $3 \mathrm{~b})$ the shear force $V_{d 2}(s)$ and the equivalent stabilizing force $q_{d 2}(s)$ are calculated from expressions:

$$
V_{d 2}(s)=16 \frac{N_{E d} e_{0}}{L} s\left(1-3 s+2 s^{2}\right)
$$




$$
q_{d 2}(s)=16 \frac{N_{E d} e_{0}}{L^{2}}\left(6 s-6 s^{2}-1\right)
$$

The distribution of compression forces $N_{2}(x)$ in the restrained chord of the roof girder (Fig. 3a) has been shown in Fig. 3b. The diagram of shear force $V_{2}(s)$ and distribution of the equivalent stabilizing force $q_{d 2}(s)$, respectively, are shown in Fig. $3 \mathrm{c}$ and $3 \mathrm{~d}$. It is momentous that at the support zone $V_{d 2}(0)=V_{d 2}(1)=0$ (there is no reaction force $R_{d 2}=0$ ).

a)

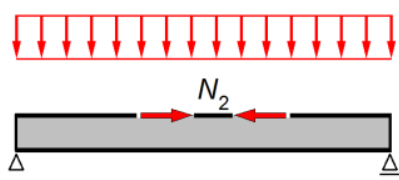

b)

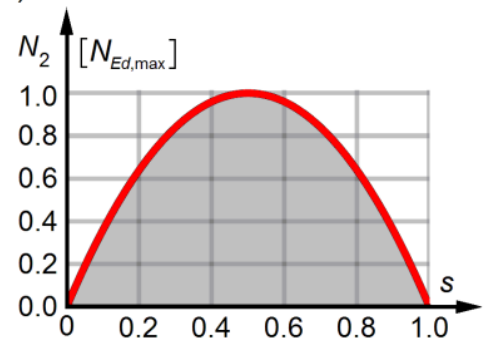

c)

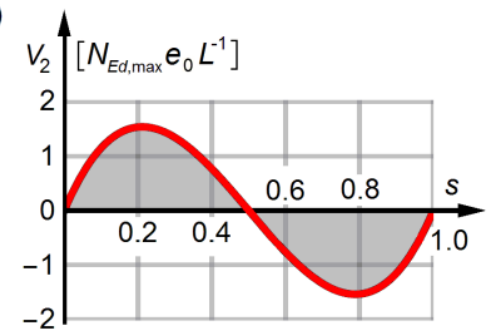

d)

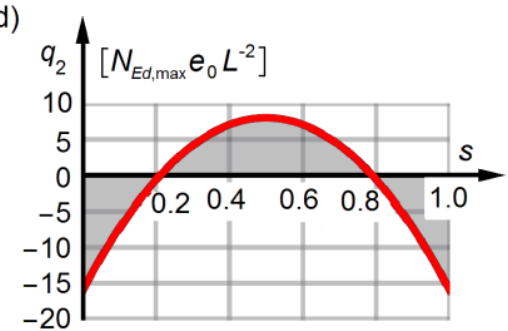

Fig. 3. Roof girder: a) static scheme, b) axial force $N_{2}(s)$ in the restrained chord, c) shear force $V_{2}(s)$ in the restrained chord, d) the equivalent stabilizing force $q_{d 2}(s)$ in the restrained chord

\section{DISCUSSION OF OBTAINED RESULTS}

The case of a constant axial force in the restrained member fits to the model of EN 1993-1-1 [4], where the compression axial force is assumed as $N_{1}(s)=$ const (Fig. 1c). Then the equivalent bow imperfection force consists of the uniform force $q_{d 1, m}$, calculated from equation (4) (Fig. 1d) and end reactions $R_{d 1, m}$ (Fig. 1d), to be calculated from formula:

$$
R_{d 1, m}=-4 \frac{e+\delta_{q 1, w}}{L} \sum_{j=1}^{m} N_{E d, j}
$$


Force $q_{d 1, m}$ together with reactions $R_{d 1, m}$ create a self-balanced system (no effects on columns' bracings). In industrial buildings the uniform force $q_{d 1, m}$ is transferred to intermediate purlins, while reactions $R_{d 1, m}$ are transferred to the eave purlins. In case of the uniform $q_{d 1, m}$ all imperfection forces $F_{d 1, m}$ in intermediate purlins have the same values and signs. For $m$ restrained members, the imperfection forces $F_{d 1, m}$ are calculated from equation:

$$
F_{d 1, m}=8 a \frac{e+\delta_{q 1, w}}{L^{2}} \sum_{j=1}^{m} N_{E d, j}
$$

where: $a$ - spacing of purlins.

The biggest imperfection forces $F_{d 1, m}(0)$ and $F_{d 1, m}(L)$ occur in eave purlins that are loaded by reactions $R_{d 1, m}$ and force $q_{d 1}$ (Fig. 1d).

These forces are calculated as:

$$
F_{d 1, m}(0)=F_{d 1, m}(L)=-4 \frac{e+\delta_{q 1, w}}{L^{2}}(L-a) \sum_{j=1}^{m} N_{E d, j}
$$

It should be mentioned that in the analysis of effects of the bow imperfection forces $q_{d 1, m}$, the procedure is limited to the intermediate purlins and bracing. Meanwhile, it is necessary to check the eave purlins due to large compression forces (much bigger from those occurring in intermediate purlins).

In the literature dealing with imperfection forces e.g. [6], and also in analyses of the behavior of the structure, the geometrical imperfections are considered to be significant for the evaluation of safety of the compression members. The analysis of internal forces of a member tensioned by a constant force $N_{1}(s)=$ const, the effects of his bow deflection are the same as for a compression. The equivalent bow imperfection forces of tensile members under the constant force consists of uniform force $q_{d 1, m}$ and reactions $R_{d 1, m}$, that have the same distribution (see Fig. 1d) and values of opposite signs from those determined from equations (1), (2), (4), (10), (11), (12). The later are transferred to purlins and bracing as in the case of compression members. It means that the initially deflected portions of the tensile members transfer the imperfection forces to bracing (like in case of compression members).

In case, when along the restrained member the non-uniform compression force $N_{2}(s)$ has a parabolic distribution, described by the relationship (6), the distribution of imperfection force $q_{d 2}(s)$ is variable as well (Fig. 3d, $4 \mathrm{~b}$ ).

The determined from equation (8) total imperfection force $q_{d 2, m}$ from $m$ restrained members transferred to the bracing (with its strain taken into account) is determined from equation: 


$$
q_{d 2, m}(s)=16 \frac{e+\delta_{q 2, w}}{L^{2}}\left(6 s-6 s^{2}-1\right) \sum_{j=1}^{m} N_{E d, j}
$$

where: $\delta_{q 2, w}$ - in-plane deflection of the lateral bracing system in the mid-span (Fig. 1a) caused by $q_{d 2}$ and all other external loads (e.g., wind load $w$ ) obtained from first order analysis (it may be assumed $\delta_{q 2, w}=0$ if second order analysis is used).

a)

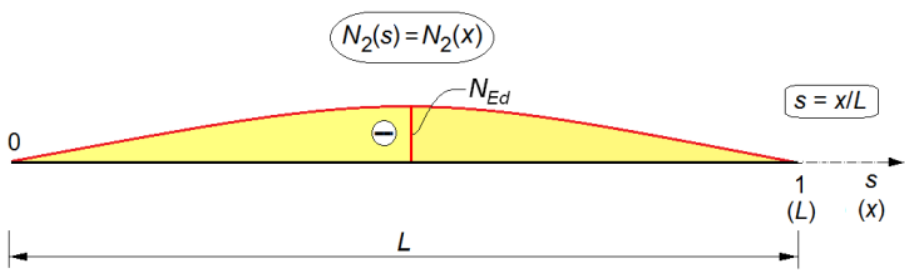

b)

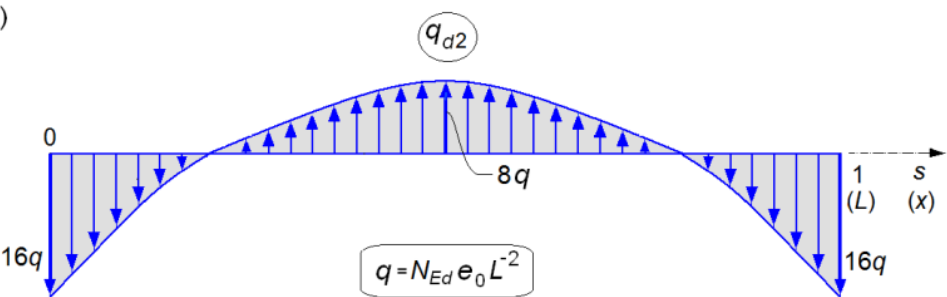

Fig. 4. a) parabolic distribution of the axial force in the member to be restrained in a single-span, free supported beam, b) imperfection force $q_{d 2}$

In case of a member's compression by a constant force, the force $q_{d 1, m}$ is balanced by reactions $R_{d 1, m}$ (Fig. 1d). When the parabolic changes of the axial force occurs, the imperfection force $q_{d 2}(s)$ is also self-balanced. But in this case reactions at the support do not appear $\left(R_{d, m}=0\right.$, because the shear force is $V_{3}(s)=0$; see Fig. 3c). Imperfection force $q_{d 2}(s)$ differs essentially from the force $q_{d 1}$ in EN 1993-1-1 [4]. For the parabolic variability of the compression force in the restrained member $N_{2}(s)$ (Fig. 3b, 4a), the distribution of the imperfection force $q_{d 2}(s)($ Fig. 3d, 4b) is variable (non-uniform) and has changes of the sign (Fig. 4b). At the distance of about $s=0.211$ from the support, the force $q_{d 2}(s)$ changes the sign. Forces $q_{d 1}(0.5)$ and $q_{d 2}(0.5)$ are the same. The biggest force $q_{d 2}(s)$ occurs at the support zone and have an opposite sign to the forces at the mid-span zone $q_{d 2}(0.5)$. Imperfection forces at the support zone $q_{d 2}(0)$ and $q_{d 2}(1)$ are twice bigger from $q_{d 2}(0.5)$ and $q_{d 1}$. The comparison of imperfection forces $q_{d 1}$ and $q_{d 2}$ shows that differences between them are significant and have a qualitative but first of all a quantitative character. This affects the state of stresses in both purlins and bracing. 
The imperfection force $q_{d 2}$ is transmitted to purlins and causes longitudinal forces $F_{d 2}$ that varies along the lateral bracing. The imperfection axial forces in intermediate purlins $F_{d 2, m, i}\left(s_{i}\right)$, and eave purlins $F_{d 2, m}(0), F_{d 2, m}(1)$ from $m$ restrained members are calculated from equations:

$$
\begin{aligned}
& F_{d 2, m, i}\left(s_{i}\right)=\int_{s_{i}-0.5 a / L}^{s_{i}+0.5 a / L} q_{d 2}(s) d s=16 a \frac{e+\delta_{q 2, w}}{L^{2}}\left(6 s_{i}-6 s_{i}{ }^{2}-1-\frac{a^{2}}{2 L^{2}}\right) \sum_{j=1}^{m} N_{E d, j} \\
& F_{d 2, m}(0)=F_{d 2, m}(1)=\int_{0}^{0.5 a / L} q_{d 2}(s) d s=4 a \frac{e+\delta_{q 2, w}}{L^{2}}\left(3 \frac{a}{L}-\frac{a^{2}}{L^{2}}-2\right) \sum_{j=1}^{m} N_{E d, j}
\end{aligned}
$$

Imperfection force $q_{d 1}\left(N_{1}(s)=\right.$ const) is uniform (Fig. 1d) and all imperfection forces $F_{d 1}$ in intermediate purlins are the same having the same sign, where as in the eave purlins large forces $R_{d 1}$ (Fig. 1d) occurs.

The force $q_{d 2}(s)$ is non-uniform and all imperfection forces $F_{d 2, m, i}$ transmitted to purlins have variable values and signs along the restrained member. In case when force $q_{d 1}$ is considered, the imperfection forces $F_{d 1, m}$ transmitted to intermediate purlins have the same values and signs. Forces in the purlins placed in the middle zone of the roof $F_{d 1, m}(0.5)$ i $F_{d 2, m}(0.5)$ are almost the same. In the intermediate purlins excluding the eave zone forces $F_{d 2, m}\left(s_{i}\right)$ are smaller from forces $F_{d 1, m}\left(s_{i}\right)$. The biggest forces $F_{d 2, m, i}$ might occur in eave purlins, but they are much smaller from the force $F_{d 1, m}(0)=F_{d 1, m}(L)$ (11) in the eave purlin. For instance in the structure shown in Fig. 1a the force in purlin eave $F_{d 2}\left(s_{i}=0\right)$ constitutes $16 \%$ of the force $R_{d 1}$.

\section{EXAMPLE 1}

The scheme of the studied roof structure is shown in the figure exposed in Table 1. Data:

- roof plate girder (Fig. 2a) with a span of $L=24 \mathrm{~m}$;

- maximum force in the restrained chord $N_{E d}=163.64 \mathrm{kN}$ (Fig. 4a);

- spacing of purlins $a=2 \mathrm{~m}$.

The diagonals of the bracing are flexible and do not resist compression forces. The longitudinal, axial forces have been analyzed in purlins and bracing's diagonals due to imperfection forces generated by 1 stabilized roof plate girder. Values of these forces for different models of imperfection are listed in Table 1. 
EQUIVALENT STABILIZING FORCE OF THE SIMPLY SUPPORTED ROOF GIRDERS 51 INCLUDING THE LONGITUDINAL VARIABILITY OF THE COMPRESSION FORCE ACTING IN THE RESTRAINED CHORD

Table 1. Axial forces in diagonals of bracing and purlins versus different models of imperfection forces

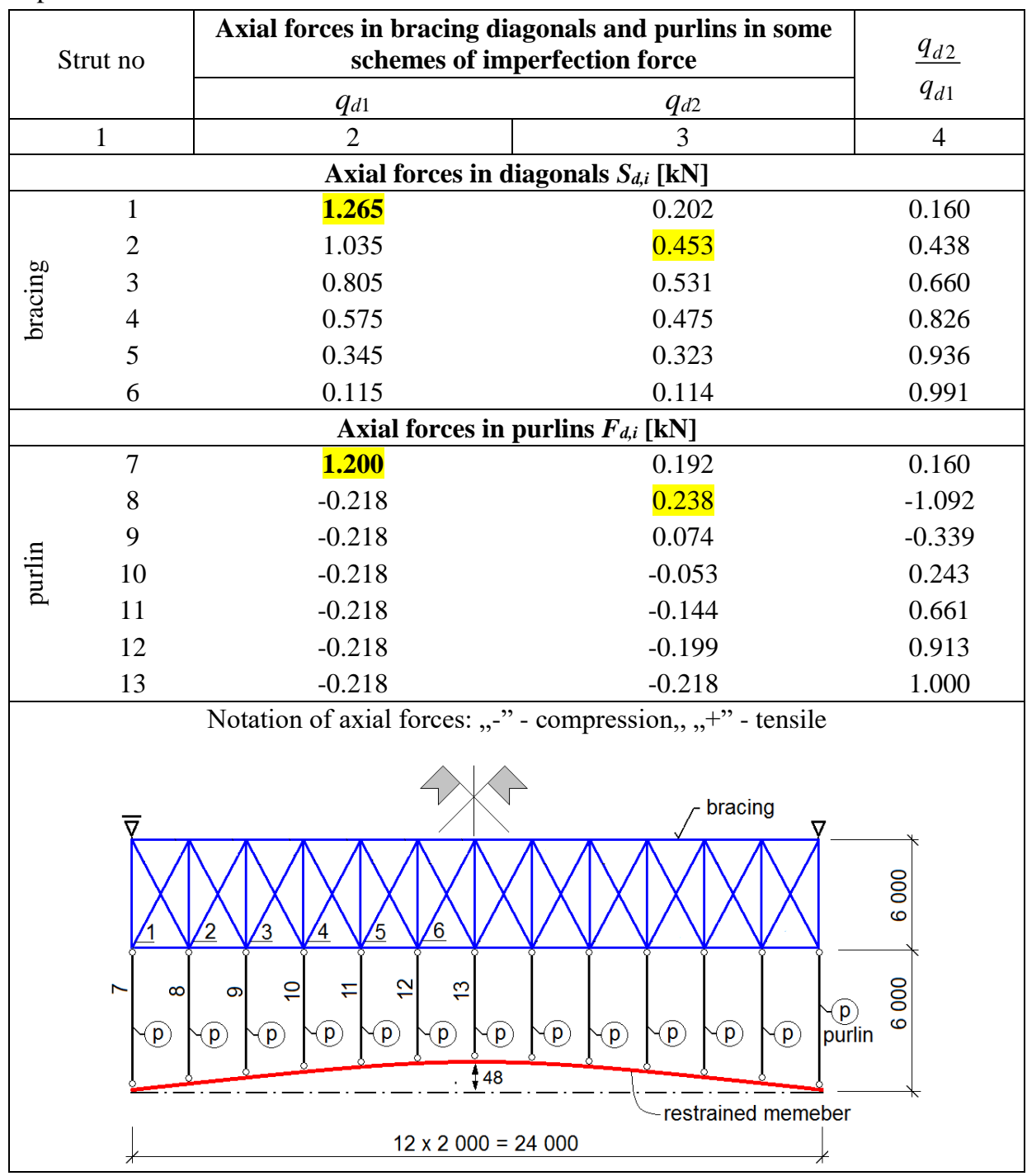

The axial forces in purlins and the bracing have been calculated according to the model with the following assumptions:

- constant compression force along the restrained chord of single-span, freesupported; under the force $q_{d 1}$ and $R_{d 1}$ (Table 1, column 2), 
- parabolic shape of distribution of the compression force in the restrained member of a single-span, free-supported; under the force $q_{d 2}$ (Table 1, column 3).

The executed calculations allow to formulate the following conclusions:

1. Assumed in the calculation model of the parabolic, real distribution of the longitudinal force in the restrained member shows, in comparison to the model recommended by EN 1993-1-1 [4], the considerable qualitative and quantitative changes of imperfection longitudinal forces in purlins and the bracing.

2. Taken into account (see Table 1 column 3 ) the parabolic distribution of the longitudinal force in the restrained chord of a single-span, simply supported roof girder (imperfection force $q_{d 2}$ ) causes in comparison to EN 1993-1-1 [4]

(Table 1, column 2; imperfection force $q_{d 1}$ ) the following effects:

- the decrease of $84 \%$ of the axial force in the eave purlins no 7 ,

- increase of $9.2 \%$ of axial force in the purlin no 8 next to the eave,

- in the model loaded by force $q_{d 1}$ the maximum force appears in the eave purlin no $7\left(S_{7}=1.200 \mathrm{kN}\right)$,

- in the model loaded by force $q_{d 2}$ the maximum force appears in the purlin no 8 next to the eave $\left(S_{8}=0.238 \mathrm{kN}\right)$,

- the axial force in the central purlin no 13 is the same for both calculation models,

- the decrease of $8.7 \%$ to $66.1 \%$ of axial forces in purlins no $9-12$,

- the decrease of $0.9 \%$ to $84 \%$ of axial forces in all diagonals of bracing,

- in the model loaded by force $q_{d 1}$ the maximum axial force (used for members' dimensioning) appears in the eave diagonals no 1 $\left(S_{1}=1.265 \mathrm{kN}\right)$,

- in the model loaded by force $q_{d 2}$ the maximum axial force (used for members' dimensioning) appears in the diagonal no 2 next to the eave $\left(S_{2}=0.453 \mathrm{kN}\right)$.

\section{CALCULATION OF THE EQUIVALENT STABILIZING AXIAL FORCES IN PURLINS BY THE METHOD OF THE EQUILIBRIUM OF FORCES IN NODES}

Alternative to the analytical determination of imperfection actions proposed in part 2, is the method based on the analysis of the equilibrium of forces in nodes placed on initially bent member to be restrained [5].

Knowing the values of axial forces in the member with initial bow imperfection (e.g., directly from the static calculation of internal forces in the roof girder) it is possible to determine individual actions $F_{d, i}$ transmitted to purlins and bracing. 
This method employs the condition of equilibrium of forces acting in nodes defined as supports of single beams inscribed in a bow deflected member to be restrained. The span of such created beams is equal to the distance between purlins. Beams a subjected to the axial force $N(x)$ varying along their length with distribution like in the restrained member. Imperfection forces $F_{d, i}$ of the restrained member transmitted to purlins and the bracing are the support reactions of the analyzed beam system (Fig. 5) can be found by equation:

$$
F_{d, i}=R_{i}=N_{i} \sin \varphi_{i}-N_{i+1} \sin \varphi_{i+1} .
$$

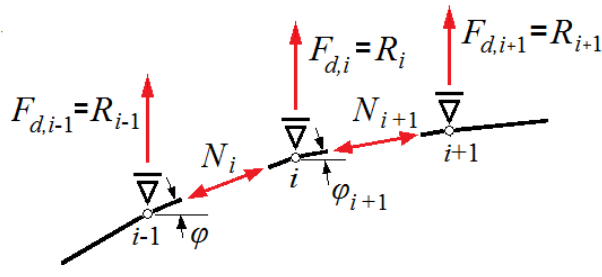

Fig. 5. Scheme of determination of imperfection forces from the condition of equilibrium of forces grouped in specified nodes

\section{EXEMPLE 2}

In order to control the correctness of the analytical model proposed in the point 2 and for presentation of the method of balancing the forces grouped in specified nodes, the analysis of imperfection force of the restrained member has been made for distribution of axial force assumed in example 1 (in plated girders - Fig. 2a, c, $3 a, b)$. The axial forces have been analyzed in purlins of the structure shown in the figure exposed in Table 1. As a calculation model 12 single-span beams have been taken (Fig. 6c). Their supports a situated on the line with initial bow imperfection $e_{0}=L / 500=24000 / 500=48 \mathrm{~mm}$.

The imperfection force transmitted to purlins has been determined as support reactions $R_{i, p}$ of analyzed 12 single-span beams (see row 3, Table 2). In row 2 in Table 2, the forces $F_{d, i}$ (see column 3 in Table 1 ) found by equations (14) and (15) i.e., are presented according to the analytical calculation model.

Comparison of forces $R_{i, p}$ and $F_{d, i}$ shows the very small differences between them (not exceeding $0.5 \%$ ). Numerically obtained forces acting in purlins are of acceptable accuracy for design practice. Thus the analysis confirm also the correctness of proposed analytical model of calculation of imperfection forces. 
a)

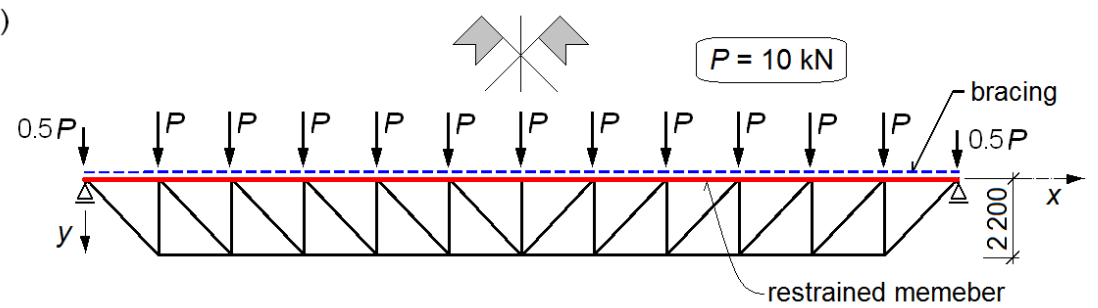

b)

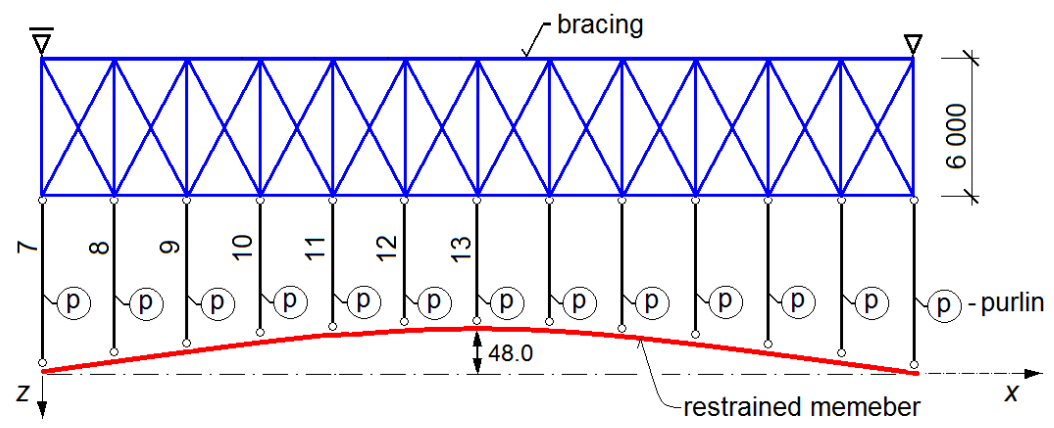

c)

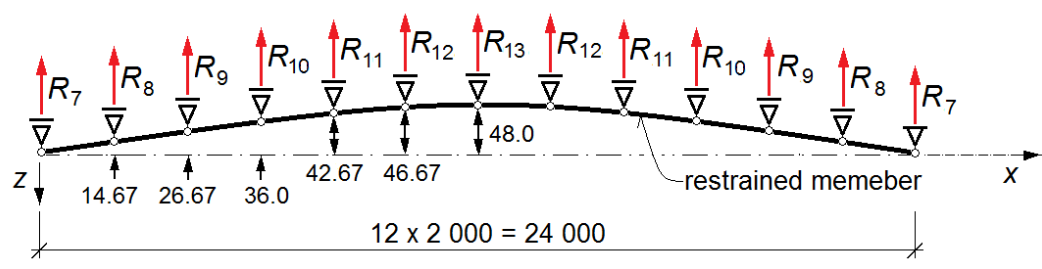

d)

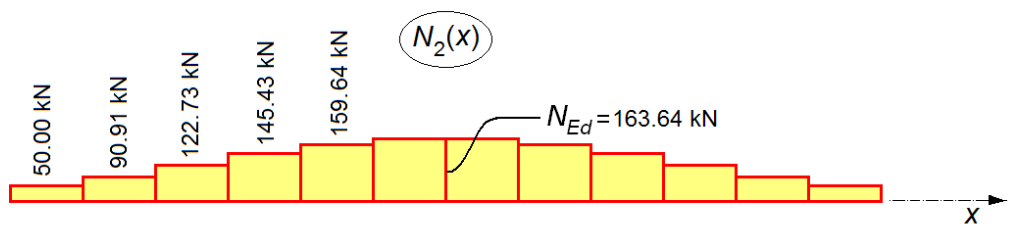

Fig. 6. Scheme of the analyzed roof bracing in example 3

Table 2. Axial forces acting in purlins due to imperfection actions found from (14) and (15) versus corresponding forces determined numerically

\begin{tabular}{|c|c|c|c|c|c|c|c|c|c|}
\hline & & Member no & 7 & 8 & 9 & 10 & 11 & 12 & 13 \\
\hline \multirow{3}{*}{ 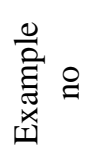 } & 1 & $F_{d, i}[\mathrm{kN}]$ & 0.192 & 0.238 & 0.074 & -0.053 & -0.144 & -0.199 & -0.218 \\
\hline & 2 & $R_{i, p}[\mathrm{kN}]$ & 0.189 & 0.238 & 0.075 & -0.052 & -0144 & -0.198 & -0.216 \\
\hline & 3 & $R_{i, t}[\mathrm{kN}]$ & 0.367 & 0.179 & 0.027 & -0.088 & -0.166 & -0.210 & -0.218 \\
\hline
\end{tabular}




\section{EXEMPLE 3}

Given in part 2 expressions for calculation imperfection forces $q_{d 2}(s)$ concern the continuous, parabolic function describing the distribution of the axial force in a restrained member (Fig. 2c, 3b). This distribution is characteristic for plate girders (Fig. 2a, 3a). In case of trusses (Fig. 2b), the distribution has a stepwise parabolic shape (Fig. 2d), and then an adequate approximation by continuous parabolic distribution should be done. The equivalent stabilizing force for restrained top chord of truss girder is easier to calculate using the method based on the analysis of the equilibrium of forces in nodes. That type of calculations were presented in this example.

The scheme of the studied roof structure shown in Fig 6.

Data:

- truss girder with a span of $L=24 \mathrm{~m}$;

- $\quad$ spacing of purlins $a=2 \mathrm{~m}$;

- $\quad$ maximum force in the restrained chord $N_{E d}=163.64 \mathrm{kN}$.

The axial forces have been analyzed in purlins of the structure shown in Fig. $6 \mathrm{~b}$. As a calculation model 12 single-span beams have been taken shown in Fig. 6c. Their supports a situated on the line with initial bow imperfection of a restrained member $e_{0}=L / 500=24000 / 500=48 \mathrm{~mm}$. Beams are subjected to the axial force $\mathrm{N}_{2}(x)$ shown in Fig. $6 \mathrm{~d}$.

The imperfection force transmitted to purlins has been determined as support reactions $R_{i, t}$ of analyzed 12 single-span beams given in row 4, Table 2.

\section{CONCLUSIONS AND FINAL REMARKS}

The model of evaluation of bow imperfection forces $q_{d 1}$ and the calculation of purlins and bracings according to EN 1993-1-1 [4] are not correct. Its use gives a faulty estimation of the internal forces acting in purlins and bracings (column 4, Table 1). It results from not been taken into account, usually parabolic distribution of the longitudinal force in the members to be restrained. Moreover, in the case of roof girders rigidly connected to the columns, the restrained part of the member is loaded by an axial force with changeable signs, parabolically variable.

If distributions of the longitudinal forces in the restrained chord have a parabolic shape then the imperfection forces $q_{d 2}$ are non-uniform with signs' changing. Thus, the obtained values may be bigger from the imperfection force $q_{d 1}$ determined by EN 1993-1-1 [4]. Demonstrated differences have a quality and quantity character. This state causes a different distribution of internal forces in purlins and the bracing in comparison with results obtained by EN 1993-1-1 [4] (extreme forces might be higher and appear in other as expected members). 
Given in part 2 expressions for calculation imperfection forces $q_{d 2}(s)$ concern the continuous, parabolic function describing the distribution of the axial force in a member. This distribution is characteristic for plate girders (Fig. 2a). In case of trusses (Fig. 2b), the distribution has a stepwise parabolic shape (Fig. 2d), and then an adequate approximation by continuous parabolic distribution should be done.

The equivalent stabilizing force for restrained top chord of truss girder is easier to calculate using the method based on the analysis of the equilibrium of forces in nodes.

The proposed evaluation of imperfection forces $q_{d 2}(s)$ allows to analyze a refined and generalized model of the behavior of purlins and bracings. The presented qualitative and quantitative differences of suggested models are bigger from those obtained by EN 1993-1-1 [4]. Therefore, appropriate corrections should be considered in the amended version of EN 1993-1-1 [4].

\section{REFERENCES}

1. Biegus A., Czepiżak D.: Global geometrical imperfections for refined analysis of lateral roof bracing systems, Recent Progress in Steel and Composite Structures - Giżejowski et. al. (Eds). XIII International Conference on Metal Structures ICMS2016, Zielona Góra, Poland 15-17 June 2016), CRC Press Taylor \& Francis Group, London 2016, 187-196.

2. Czepiżak D., Biegus A.: Refined calculation of lateral bracing systems due to global geometrical imperfections, Journal of Constructional Steel Research, 119 (2016) 30-38.

3. Gardner M., Nethercot D.: in: H. Gulvanessian (Ed.) Designers Guide to EN 1993-1-1: Eurocode 3 Design of Steel Structures. Part 1-1: General Rules and Rules for Building, Thomas Telford Limited, London, 2005.

4. EN 1993-1-1, Eurocode 3: Design of Steel Structures. Part 1-1: General Rules and Rules for Building, CEN, Brussels, 2005.

5. Pałkowski Sz., Piątkowski M.: On the calculation of lateral roof bracing, Inżynieria i Budownictwo 4 (2014) 210-213 [in Polish].

6. Taylor J.C., et al.: Interim Guidance on the Use of Eurocode 3: Eurocode 3 Part 1-1: for European Design of Steel Building Structures, The Steel Construction Institute, Ascot, 1995.

7. Trahair N.S., Bradford M.A., Nethercot D.A., Gardner L.: The Behavior and Design of Steel Structures to EC3, Taylor and Francis, London-New York, 2008. 


\section{OBCIĄŻENIE IMPERFEKCYJNE PRZEGUBOWO PODPARTYCH DŹWIGARÓW DACHOWYCH Z UWZGLĘDNIENIEM WZDŁUŻNEJ ZMIENNOŚCI SIŁY ŚCISKAJĄCEJ W ICH STĘŻANYM PASIE}

\section{Streszczenie}

W modelu obliczeniowym oddziaływań imperfekcyjnych $q_{d}$ oraz wytężenia płatwi i stężeń przyjęto w EN 1993-1-1 jako bezpieczne założenie, że stężany pas górny dźwigara dachowego jest ściskany siłą stałą na jego długości. Założenie to nie jest poprawne, gdyż rozkład siły osiowej w stężanym pasie dźwigara dachowego zmienia się wzdłużnie. Jest on zazwyczaj paraboliczny, a także może być też znakozmienny (np. w przypadku rygla dachowego sztywno połączonego ze słupami, w jego stężanym pasie górnym występuje ściskanie i rozciąganie). Powoduje to generowanie odmiennego oddziaływania imperfekcyjnego przekazywanego na płatwie i stężenie, niż obliczone wg modelu rekomendowanego w EN 1993-1-1.

Przedmiotem pracy są analizy obciążeń imperfekcyjnych stężanych pasów górnych dźwigarów dachowych, które są podparte przegubowo. Siła osiowa w stężanych pasach górnych zmienia się parabolicznie na ich długości i jest największa w środku rozpiętości dźwigara dachowego. Podano zależności analityczne służące do wyznaczania oddziaływań imperfekcyjnych stężanych pasów górnych badanych dźwigarów dachowych, w których występuje wzdłużna, paraboliczna zmienność siły osiowej. Wykonano analizę porównawczą zaproponowanego, uściślonego modelu wyznaczania obciążeń imperfekcyjnych $\mathrm{z}$ modelem obliczeniowym wg PN-EN 1993-1-1. Przedstawiono również alternatywny sposób wyznaczania oddziaływań imperfekcyjnych w stężanym pasie dźwigarów dachowych. Polega on na analizie równowagi sił w węzłach lukowego (wstępnie wygiętego) stężanego pasa górnego dźwigara dachowego. Ten sposób jest szczególnie przydatny w obliczeniach oddziaływań imperfekcyjnych kratownicowych dźwigarów dachowych. Przeprowadzono dyskusję otrzymanych wyników badań i zilustrowano analizowane zagadnienia przykładami obliczeniowymi.

Słowa kluczowe: konstrukcje stalowe, stężenia dachowe, obciążenia imperfekcyjne, dźwigar dachowy, stężany pręt, płatew

Editor received the manuscript: 16.07.2016 